\title{
INOVASI PEMBUATAN KULIT MOONCAKE DARI TEPUNG KACANG MERAH
}

\author{
[Innovation for Making Mooncake Skin from Red Bean Flour] \\ Saleha $^{1)}$, Dhanik Puspita Sari ${ }^{2)}$ Tasya Maulidina ${ }^{3) *}$ \\ 1)Program Studi Manajemen Perhotelan, Sekolah Tinggi Pariwisata Bogor \\ 2)Program Studi Pariwisata Parwisata, Sekolah Tinggi Pariwisata Bogor \\ 3) Program Studi Manajemen Perhotelan, Sekolah Tinggi Pariwisata Bogor
}

Diterima Februari 2022 / Disetujui Februari 2022

\begin{abstract}
The purpose of this study was to obtain a suitable recipe for making mooncake skins made from local food, namely red bean flour and to determine the level of public preference for this innovative product. The research method used is quantitative research, and distributing questionnaires to the panelists in conducting a preference test or organoleptic test on the taste, color, aroma and texture of the product. Processing of data from the results of the questionnaire was processed using descriptive statistics. The results obtained after conducting pre-experiments the authors get the right results for research by providing questionnaires and product samples to expert panelists and consumer panelists, the formulation used is the P2 formulation using $85 \%$ red bean flour $15 \%$ wheat flour and the P3 formulation using $100 \%$ red bean flour. The conclusion of this study is from the 2 formulations obtained and seen from the mean, median, mode, and standard deviation of the results of the organoleptic test questionnaire to expert panelists and consumer panelists, it can be concluded that the preferred formulation is in terms of taste, aroma, color and texture are P3 formulations using $100 \%$ red bean flour with an average value of 3.5 for expert panelists and 3.32 for consumer panels.
\end{abstract}

Keywords: Mooncake, Chinese Food, Red Bean Flour

\begin{abstract}
ABSTRAK
Tujuan penelitian ini untuk mendapatkan resep yang sesuai dalam pembuatan kulit mooncake berbahan pangan lokal yaitu tepung kacang merah dan untuk mengetahui tingkat kesukaan masyarakat terhadap produk inovasi ini. Metode penelitian yang digunakan adalah penelitian kuantitatif, dan menyebarkan kuesioner kepada para panelis dalam melakukan uji kesukaan atau uji organoleptik terhadap rasa, warna, aroma dan tekstur produk tersebut. Pengolahan data dari hasil kuesioner diolah menggunakan statistik deskriptif. Didapatkan hasil penelelitan setelah melakukan pra eksperimen penulis mendapatkan hasil yang tepat untuk penelitian dengan memberikan kuesioner dan sampel product kepada panelis ahli dan panelis konsumen, formulasi yang digunakan adalah formulasi P2 dengan menggunakan 85\% tepung kacang merah 15\% tepung terigu dan formulasi P3 menggunakan 100\% tepung kacang merah. Kesimpulan dari penelitian ini adalah Dari 2 formulasi yang didapatkan dan dilihat dari nilai mean, median, modus, dan standar deviasi hasil dari kuesioner uji organoleptik terhadap para panelis ahli dan panelis konsumen maka dapat ditarik kesimpulan bahwa formulasi yang lebih di sukai baik dari segi rasa, aroma, warna dan tekstur adalah formulasi P3 dengan menggunakan $100 \%$ tepung kacang merah dengan nilai rata-rata panelis ahli 3,5 dan panelis konsumen 3,32.
\end{abstract}

Kata Kunci: Mooncake, Makanan Khas Tionghoa, Tepung Kacang Merah. 


\section{PENDAHULUAN}

Indonesia terkenal dengan tanahnya yang subur sehingga mempunyai potensi tinggi menghasilkan produk pertanian, terutama bahan pangan. Diantara bahan pangan yang tersedia cukup banyak di Indonesia, salah satunya adalah kacang-kacangan dengan jenis yang cukup banyak dan mudah didapatkan.

Kacang merah atau Kacang jago termasuk kacang-kacangan yang banyak terdapat di seluruh pelosok tanah air dan juga merupakan jenis kacang-kacangan yang banyak terdapat di pasarpasar tradisional maupun modern sehingga mudah didapatkan. Kacang merah atau dalam bahasa ilmiah disebut Phaseolus vulgaris $L$. berasal dari Amerika, penyebarluasan tanaman kacang merah dari Amerika ke Eropa dilakukan sejak abad 16. Daerah pusat penyebaran adalah Inggris dan pengembangan dimulai sejak tahun 1592 ke negara-negara Eropa dan Afrika hingga ke Indonesia.

Kacang merah kaya akan asam folat, kalsium, karbohidrat kompleks, serat, dan protein yang tergolong tinggi. Kandungan karbohidrat kompleks dan serat yang tinggi dalam kacang merah dapat menurunkan kadar kolesterol darah. Kadar indeks glikemik kacang merah juga termasuk rendah, sehingga menguntungkan penderita diabetes dan menurunkan risiko timbulnya diabetes.

Pemanfaatan kacang merah sebagai alternatif menu baru untuk menambah protein dalam tubuh belum banyak dilakukan, dalam pemanfaatannya masih monoton dan belum ada variasi. Di dalam pengolahan makanan contohnya pemanfaatan kacang merah di Indonesia sampai saat ini masih terbatas sebagai pelengkap menu dalam mengkonsumsi makanan sehari-hari seperti sayuran, sup kacang merah dan lain-lain. Dengan sistem pengolahan tersebut, produk tidak dapat disimpan lama dan nilai ekonomisnya rendah.

Pengolahan kacang merah menjadi tepung kacang merah telah lama dikenal oleh masyarakat, tetapi pada er ini diperlukan teknologi untuk meningkatkan mutu tepung kacang merah yang lebih baik. Untuk meningkatkan kualitas gizi dan nilai ekonomis, tepung kacang merah bisa menjadi pengganti tepung terigu. Tepung kacang merah dibuat dari kacang merah asli yang diolah dengan proses pembersihan,perendaman,pengeringan, dan penggilingan.

Korespondensi Penulis:

E-mail: puspitasaridhanik@gmail.com
Keunggulan dari pengolahan kacang merah menjadi tepung kacang merah adalah meningkatkan daya guna, hasil guna dan nilai guna, lebih mudah diolah atau diproses menjadi produk yang memiliki nilai ekonomi tinggi, lebih mudah dicampur dengan tepung-tepung lain dan bahan lainnya (Marlinda Retno Budya, 2012) akan mengembangkan tepung kacang merah menjadi sebuah produk makanan yang sangat digemari dunia kuliner yaitu mooncake atau kue bulan.

Mooncake atau kue bulan adalah salah satu makanan tradisional masyarakat Tionghoa yang dikenalkan oleh para imigran perantauan dari Tiongkok yang datang ke Indonesia, secara umum mooncake berbentuk bundar atau persegi dan memiliki diameter $10 \mathrm{~cm}$ dengan memiliki ketebalan 4-5 cm serta memiliki isian berupa pasta padat dan liat berada dalam kulit tipis sekitar 2-3 mm. Isi dari mooncake biasanya manis, sedikit asin. Bagian tengah mooncake biasanya berisi kuning telur asin, yang di dalamnya mengandung arti bulan purnama dan uang emas. Ini sesuai dengan budaya Tionghoa, di mana segala jenis perayaan biasa dihubungkan dengan kesejahteraan, kemakmuran, kebahagian, Panjang umur, atau kesehatan.

Festival Kue Bulan atau Mooncake Festival, diperingati hari ke-15 bulan kedelapan kalender China. Mooncake pada umumnya dibuat untuk memeriahkan pesta atau sekedar berkumpul bersama keluarga sambil meneguk teh khas China yang pahit. Mooncake juga selalu ada dalam perayaan tahunan sebagai penanda akhir musim panen.

Secara tradisional mooncake isinya bisa dibagi menjadi empat, yaitu lotus seed paste, sweet been paste (dou sha, sering dilafalkan tau sa di Indonesia), jujube paste, dan five kernel. Sedangkan jenis kulit mooncake ada beberapa jenis yaitu Chewy, Flaky, Tender. Lalu ada pula jenis-jenis mooncake yaitu Cantonese style mooncake, Suzhou style mooncake, Beijing style mooncake, Chaoshan style mooncake, Ningbo style mooncake dan Yunnan style mooncake.

Jenis mooncake yang sekarang banyak terkenal dan banyak dijumpai di seluruh dunia yaitu Cantonese style mooncake dengan jenis kulit Chewy, kulit mooncake ini paling disukai dan terbuat dari bahan tepung terigu, golden syrup, dan sedikit mintak. Mooncake populer dengan isi tausa kacang merah, kacang hijau, coklat, dan ice cream. Peneitian ini bermanfaat dalam menemukan resep yang tepat untuk membuat kulit mooncake dari subtitusi tepung kacang 


\section{METODE PENELITIAN}

\section{Alat dan Bahan Penelitian}

Berikut alat dan bahan yang digunakan untuk membuat mooncake:

\begin{abstract}
Alat Yang Digunakan
Mixer Bowl, wadah untuk mengaduk adonan. Hand Chopper alat untuk menhaluskan kacang merah. Stewpan alat untuk merebus kacang merah. Frying Pan alat untuk mengolah kacang merah menjadi tausa. Spatula alat untuk mengaduk adonan kulit mooncake. Measuring Spoon alat untuk menguku bahan mooncake. Digital Scale alat untuk menimbang bahan-bahan mooncake. Oven alat untuk memanggang mooncake. Stove alat untuk memasak tausa Baking Sheet wadah saat memanggang. Baking Paper untuk melapisi baking sheet agar mooncake tidak lengket. Mooncake Mold alat untuk mencetak adonan mooncake. Hand Glove agar adonan mooncake tetap higienis
\end{abstract}

\section{Bahan Penelitian}

Honey (madu) untuk bahan campuran pembuatan adonan kulit mooncake yang biasanya menggunakan golden syrup, untuk memberikan rasa manis terhadap adonan tekstur Honey yang kental juga membantu untu menyatukan adonan kulit mooncake. Lye Water untuk memberikan tekstur yang renyah pada kulit mooncake. Vegetable Oil untuk menjag tekstur mooncake lebih lembut, moist, dan tidak kering

Baking soda dapat meningkatkan kadar $\mathrm{pH}$ guna menghasilkan makanan yang tidak terlalu kenyal dan lebih empuk. Wheat Flour salah satu bahan pokok dalam pembuatan kue, tepung yang biasa digunakan untuk membuat adonan mooncake biasanya tepung protein tinggi, hasil gilingan dari gandum keras dan memiliki kadar protein antara $1113,5 \%$. Tepun protein tinggi memiliki gluten yang tinggi, membuat adonan lebih elastis dan dapat membentuk struktur yang kuat. Read Bean Flour adalah salah satu tepung bebas gluten. Red Bean sebagai isian mooncake yang nantinya akan dijadikan tau sa. Glutinous Rice Flour merupakan bahan tambahan dalam pembuatan tau sa agar adonan kenyal. Law Sugar merupakan bahan tambahan dalam pembuatan tau sa sebagai rasa manis. Salt untuk tambahan rasa pada saat kacang merah direbus. Daun pandan untuk tambahan aroma pada saat kacang merah direbus

\section{Tempat dan Waktu Penelitian}

Tempat dan waktu penelitian pembuatan design product eksperimen ini di Kitchen Lab Sekolah Tinggi Pariwisata Bogor.

\section{Prosedur Pengolahan}

Prosedur pengolahan atau tahapantahapan yang digunakan untuk mengumpulkan data guna menjawab pertanyaan dalam penelitian yang diajukan di dalam penelitian ini, dengan pembahasannya tentang desain penelitian (tahap persiapan, tahap pelaksanaan dan tahap pelaporan), instrument penelitian, proses pengembangan instrument, Teknik pengumpulan data dan analisis data (Ayu Sri Utami, 2013).

\section{Metode Pengolahan}

Pengolahan Mooncake 100\% Tepung Kacang merah, waktu Penyajian 45 meni dengan hasil 10 porsi/20 gr

Tabel 1. Bahan kulit Mooncake 100\% Tepung KacangMerah

\begin{tabular}{|c|c|c|}
\hline No. & Bahan Kulit & Jumlah \\
\hline & Tepung & \\
\hline 1 & Kacang Merah & $100 \mathrm{gr}$ \\
\hline 2 & Honey/Madu & $70 \mathrm{gr}$ \\
\hline 3 & Vegetable Oil & $30 \mathrm{gr}$ \\
\hline 4 & Lye Water & $1 \mathrm{gr}$ \\
\hline \multirow[t]{2}{*}{5} & Baking Soda & $0,4 \mathrm{gr}$ \\
\hline & Bahan Isian & Jumlah \\
\hline 1 & Red Bean & $250 \mathrm{gr}$ \\
\hline 2 & Water & $2 \mathrm{lt}$ \\
\hline 3 & Salt & $3 \mathrm{gr}$ \\
\hline 4 & Daun Pandan & $3 \mathrm{lbr}$ \\
\hline 5 & Vegetable Oil & $10 \mathrm{ml}$ \\
\hline 6 & Low sugar & $50 \mathrm{gr}$ \\
\hline 7 & $\begin{array}{c}\text { glutinous rice } \\
\text { flour }\end{array}$ & $50 \mathrm{gr}$ \\
\hline 8 & Margarine & $15 \mathrm{gr}$ \\
\hline 9 & Salted egg yolk & $5 \mathrm{btr}$ \\
\hline
\end{tabular}

Cara Membuat

1. Masukan Tepung Kacang Merah secara perlahan. 
2. Campurkan honey, vegetable oil, lye water, dan baking soda. Aduk hingga tercampur dan hingga kalis

3. Bagi adonan kulit mooncake, bulatkan dan pipihkan lalu masukan isian

4. Lalu cetak dengan cetakan mooncake.

5. Panaskan oven disuhu $110^{\circ} \mathrm{c}$ api atas bawah.

6. Panaskan oven disuhu $110^{\circ} \mathrm{c}$ api atas bawah.

7. Pembakaran

8. Hidangkan

\section{Rancangan Percobaan}

Pada penelitian yang kami lakukan perlakuan pada tepung kacang merah di dalam produk mooncake. Perlakuan yang dibuat oleh penulis berjumlah 2 kali perlakuan terhadap tepung kacang merah didalam produk mooncake dan 1 kali perlakuan mooncake tanpa tepung kacang merah, Adapun ilustrasi perlakuan menggunakan $100 \%$ tepung terigu yang merupakan bahan original mooncake (produk P1) sebagai produk pembanding, pembuatan mooncake dengan $85 \%$ tepung kacang merah dan $15 \%$ tepung terigu sebagai inovasi produk (Produk P2) dan $100 \%$ tepung kacang merah (produk P3).

\section{Tabel 2. Rancangan Percobaan}

\begin{tabular}{|c|c|c|}
\hline Percobaan & Tepung Terigu & Tepung Kacang Merah \\
\hline P1 & $100 \%$ & \\
\hline P2 & $15 \%$ & $85 \%$ \\
\hline P3 & & $100 \%$ \\
\hline
\end{tabular}

Sumber: Penulis, 2021

\section{Resep Uji Coba Produk}

Dibawah ini adalah resep atau formulasi uji coba produk terhadap pembuatan kulit mooncake.

\section{Tabel 31. Resep Uji Coba Produk}

\begin{tabular}{lllll}
\hline No & $\begin{array}{l}\text { Bahan Kulit } \\
\text { Mooncake }\end{array}$ & P1 & P2 & P3 \\
\hline 1 & Honey & $70 \mathrm{gr}$ & $70 \mathrm{gr}$ & $70 \mathrm{gr}$ \\
\hline 2 & Vegetable Oil & $30 \mathrm{gr}$ & $30 \mathrm{gr}$ & $30 \mathrm{gr}$ \\
\hline 3 & Baking Soda & $1 \mathrm{gr}$ & $1 \mathrm{gr}$ & $1 \mathrm{gr}$ \\
\hline 4 & Lye Water & $1 \mathrm{gr}$ & $1 \mathrm{gr}$ & $1 \mathrm{gr}$ \\
\hline 5 & $\begin{array}{l}\text { Tepung } \\
\text { Terigu }\end{array}$ & $100 \mathrm{gr}$ & $15 \mathrm{gr}$ & 0 \\
\hline 6 & $\begin{array}{l}\text { Tepung } \\
\text { Kacang } \\
\text { Merah }\end{array}$ & 0 & $85 \mathrm{gr}$ & 100 \\
& & & $\mathrm{gr}$ \\
\hline
\end{tabular}

Sumber Penulis 2021
Table 4. Hasil Uji Coba Produk

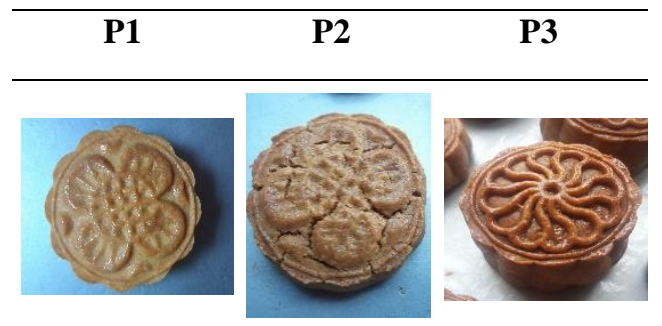

\begin{tabular}{|c|c|c|}
\hline $\begin{array}{l}\text { Memiliki } \\
\text { aroma madu } \\
\text { yang khas, } \\
\text { warna putih } \\
\text { kecoklatan, } \\
\text { dengan } \\
\text { tekstur } \\
\text { lembut dan } \\
\text { memiliki } \\
\text { rasa manis } \\
\text { yang pas. }\end{array}$ & $\begin{array}{l}\text { Memiliki } \\
\text { aroma } \\
\text { madu dan } \\
\text { tepung } \\
\text { kacang } \\
\text { merah } \\
\text { yang khas } \\
\text { dan sedikit } \\
\text { memiliki } \\
\text { aroma } \\
\text { tepung } \\
\text { terigu, } \\
\text { warna } \\
\text { coklat } \\
\text { pucat, } \\
\text { tekstur } \\
\text { permukaan } \\
\text { mooncake } \\
\text { retak } \\
\text { ketika } \\
\text { proses } \\
\text { pemasaska } \\
\text { n tetapi } \\
\text { renyah saat } \\
\text { dimakan } \\
\text { dan } \\
\text { memiliki } \\
\text { rasa manis } \\
\text { namun } \\
\text { terasa } \\
\text { asam dan } \\
\text { pahit } \\
\text { setelah di } \\
\text { makan. }\end{array}$ & $\begin{array}{l}\text { Memiliki } \\
\text { aroma madu } \\
\text { dan tepung } \\
\text { kacang } \\
\text { merah yang } \\
\text { sangat khas, } \\
\text { warna coklat } \\
\text { mengkilap, } \\
\text { tektur } \\
\text { merata dan } \\
\text { lembut saat } \\
\text { dimakan, } \\
\text { serta } \\
\text { memiliki } \\
\text { rasa manis } \\
\text { madu dan } \\
\text { manis dari } \\
\text { isian tetapi } \\
\text { terasa pahit } \\
\text { setelah } \\
\text { merasakann } \\
\text { ya. }\end{array}$ \\
\hline
\end{tabular}

Sumber: Penulis, 2021

Dalam pembuatan kulit mooncake tersebut, jenis an tepung, lye water, syrup gula kental dan minyak. Dengan isian tau sa kacang merah dan kuning telur asin. Tetapi penulis memakai bahan lain dalam pembuatan kulit dan isian mooncake tersebut, seperti tepung yang digunakan oleh penulis dalam pembuatan kulit mooncake adalah tepung kacang merah, syrup gula yang di ganti dengan madu, dan saat pembuatan isian mooncake atau tau sa kacang merah penulis mengganti jenis 
gula dengan gula rendah kalori dan menggunakan tepung beras ketan dalam pencampuran pembuatan tau sa kacang merah. Tujuannya adalah penulis ingin produk tersebut bisa menjadi salah satu makanan sehat dan bisa di konsumsi oleh para penderita diabetes dan kolesterol.

\section{HASIL DAN PEMBAHASAN}

Tabel 5. Skala Uji Kesukaan Produk demikian kuesioner merupakan daftar pertanyaan yang dibuat oleh peneliti, berkaitan dengan permasalahan penelitian dan akan dijawab oleh responden.

Kuesioner memiliki tiga jenis yaitu kuesioner terbuka dan tertutup, dan kuesioner campuran. kuesioner yang akan penulis gunakan untuk pembuatan penelitian ini adalah kuesioner tertutup, kuesioner tertutup merupakan kuesioner yang daftar pertanyaannya disertai dengan jawaban yang sudah peneliti buat.

\begin{tabular}{llll}
\hline Indikator & $\begin{array}{c}\text { Tingkat } \\
\text { Kesukaan }\end{array}$ & Skala Penilaian & $\begin{array}{l}\text { 2)Tinjauan Pustaka } \\
\text { Tinjauan Pustaka adalah metode pengumpulan } \\
\text { data dengan cara mengumpulkan data-data dari }\end{array}$ \\
\hline Warna & $\begin{array}{l}\text { Tingkat } \\
\text { kesukaan } \\
\text { terhadap }\end{array}$ & $4=$ Sangat Suka & $\begin{array}{l}\text { berbagai sumber terdahulu yang bersangkutan } \\
\text { dengan penelitian tersebut. }\end{array}$
\end{tabular}

\section{Jenis dan Sumber Data}

Jenis data dan sumber data yang di gunakan dalam penelitian ini adalah sebagai berikut:

\section{Jenis Data}

Jenis data yang di gunakan adalah data kuantitatif. Menurut Sugiyono (2015:23) Data kuantitatif adalah data yang berbentuk angka atau diberikan skor. Data tersebut biasanya diperoleh dengan menggunakan alat pengumpul data yang jawabanya berupa skor atau pertanyaan yang di beri bobot. Peneliti memperoleh data dari kuesioner yang dibagikan pada panelis. Panelis akan melakukan uji organoleptik pada pembuatan mooncake dengan tepung kacang merah, penulis menggunakan panelis ahli dalam bidang makanan yang berjumlah 2 orang dan panelis konsumen yang berjumlah 50 orang.

\section{Sumber Data}

Sumber data yang digunakan adalah sumber data primer, Sumber data ini penulis dapatkan dari kuesioner yang diajukan pada panelis.

\section{Teknik Pengolahan Data}

Setelah penulis mendapatkan data terkait dengan penelitian yang sedang dilaksanakan maka selanjutnya di lakukan analisis data, dari hasil kuesioner yang penulis dapatkan. Pengolahan data yang penulis gunakan adalah menggunakan statistik deskriptif untuk mencari nilai :

Nilai Rata-Rata (Mean)

Menurut Sugiarto dkk (2015:233) Nilai rata-rata atau Mean adalah jumlah nilai-nilai data dibagi oleh banyaknya obeservasi.

$$
\text { Mean }=\bar{x}=\frac{\sum f x}{n}
$$

Nilai Tengah (Median) Menurut Sugiarto dkk (2015:233) Median adalah nilai yang terletak 
ditengah bila nilai-nilai pengamatan disusun secara teratur menurut besarnya data.

$$
\text { Median }=L_{m}+\left[\frac{\frac{n}{2}-f}{f_{m}}\right] \cdot i
$$

Nilai yang sering muncul (Modus)

Menurut Sugiarto dkk (2015:235). Nilai yang sering Muncul atau Modus adalah nilai yang mempunyai frekuensi terbesar dalam suatu kumpulan data.

$$
\text { Modus }=L_{m o}+\left[\frac{\Delta 1}{\Delta 1+\Delta 2}\right]
$$

Standar Deviasi

Standar Deviasi atau simpangan baku adalah ukuran-ukuran keragaman (Variasi) data statistik yang paling sering digunakan.Standar deviasi (simpangan baku) merupakan akar kuadrat dari varrian.

$$
\text { Standar Deviasi }=S=\sqrt{\sum \frac{\left(x_{1}-\bar{x}\right)^{2}}{n}}
$$

\section{HASIL DAN PEMBAHASAN}

\section{Hasil dan Pembahasan}

Pada bab ini disajikan hasil dan pembahasan dari penelitian yang sudah dilakukan dengan didapatkannya formulasi yang ideal dengan melakukan penyebaran kuesioner. Kuesioner di berikan kepada penelis ahli yang merupakan ahli dalam bidang makanan. Lalu panelis konsumen yang merupakan masyarakat sekitar yang beralamat di Jl.Raya Leuwiliang, Jl.Raya Paku leuwisadeng, Desa Hambaro dan di Desa Cibeber Nanggung.

Adapun pada saat pra penelitian atau pra eksperimen dilakukan uji coba untuk mencari formulasi yang ideal. Pertama melakukan pra eksperimen membuat adonan kulit mooncake dengan formulasi original atau P1 menggunakan $100 \%$ tepung terigu, formulasi kedua atau P2 dengan pencampuran $85 \%$ tepung kacang merah $15 \%$ tepung terigu, dan formulasi ketiga atau P3 menggunakan $100 \%$ tepung kacang merah.

\section{Hasil Penelitian}

Setelah melakukan pra eksperimen didapatkan hasil yang tepat untuk penelitian dengan memberikan kuesioner dan sampel product kepada panelis ahli dan panelis konsumen, formulasi yang digunakan adalah formulasi P2 yang menggunakan $85 \%$ tepung kacang merah $15 \%$ tepung terigu dan formulasi P3 menggunakan $100 \%$ tepung kacang merah.

Dalam penyebaran kuesioner ini penulis menyebarkan kepada 2 panelis ahli, yaitu Bapak Bambang Supomo Dosen Pastry Bakery pada Sekolah Tinggi Pariwisata Bogor dan bererpengalaman pada Mai Regent Singapore (Corporate Chef 2008 - 2010 ), Hotel ües Colonie \& Arion Restaurant ( Corporate Chef ) 2006 2008. Al Ghufran Makkah 2003 -2005, serta Chef Chepi Gunawan yang merupakan Demi Chef di Hotel The Langham Jakarta.

Selain kedua panelis ahli, disebarkan pula kuesioner kepada para 50 panelis konsumen yang dimulai dari tanggal 4 juli-6 juli 2021 setelah dilakukan pencarian formulasi ideal pada tanggal 22 mei-19 juni 2021.

\section{Hasil Formulasi}

Adapun hasil formulasi Inovasi Tepung Kacang Merah dalam pembuatan Kulit Monncake, setelah dilakukan pra eksperimen seperti di bawah ini:

\begin{tabular}{ccc} 
No & Bahan Kulit & Jumlah \\
\hline & $\begin{array}{c}\text { Tepung Kacng } \\
\text { Merah }\end{array}$ & 85 gram \\
\hline 2 & Tepung Terigu & 15 gram \\
\hline 3 & Honey & 70 gram \\
\hline 4 & Vegetable Oil & 30 gram \\
\hline 5 & Lye Water & 1 gram \\
\hline 6 & Baking Soda & 0,4 gram
\end{tabular}

a. Formulasi P2

Tabel 6 Bahan Kulit Mooncake 85\%

Tepung Kacang Merah dan 15\% Tepung Terigu.

Sumber: Penulis, 2021

\section{b. Formula P3}

Tabel 7 Bhn Kulit Mooncake 100\% Tepung Kacang Merah 


\begin{tabular}{ccc} 
No & Bahan Kulit & Jumlah \\
\hline & $\begin{array}{c}\text { Tepung Kacng } \\
\text { Merah }\end{array}$ & 1005 gram \\
\hline 2 & Honey & 70 gram \\
\hline 3 & Vegetable Oil & 30 gram \\
\hline 4 & Lye Water & 1 gram \\
\hline 5 & Baking Soda & 0,4 gram \\
\hline
\end{tabular}

Sumber: Penulis, 2021

\section{Dimensi Rasa, Warna, Aroma, dan Tekstur}

Berikut adalah hasil dari pengolahan data mean, median, modus, dan standar deviation terhadap dimensi rasa, warna, aroma, dan tekstur dari fomulasi kedua dan formulasi ketiga yang penulis dapatkan dari hasil kuesioner yang penulis bagikan kepada para panelis ahli dan panelis konsumen.

\section{Hasil Data Berdasarkan Aspek Rasa}

\section{Panelis Ahli}

Jumlah panelis ahli yang tidak suka terhadap rasa formulasi P2 berjumlah 1 orang $(50 \%)$ dan suka terhadap rasa formulasi P2 berjumlah 1 orang $(50 \%)$. Dengan nilai rata-rata mean menunjukkan angka 2,50, nilai tengah median menunjukkan angka 2,50 nilai yang sering muncul modus menunjukkan angka 2 dan hasil nilai standar deviasi menunjukkan angka 0,707. Dan garis kontinum hasil rasa formulasi P2 menunjukan nilai 2,50 yang menunjukkan kategori tidak suka.

Jumlah panelis ahli yang suka terhadap rasa formulasi P3 berjumlah 1 orang (50\%) dan sangat suka terhadap rasa formulasi P3 berjumlah 1 orang $(50 \%)$. Dengan nilai rata-rata mean menunjukkan angka 3,50 , nilai tengah median menunjukkan angka 3,50 , nilai yang sering muncul modus menunjukkan angka 3 dan hasil nilai standar deviasi menunjukkan angka 0,707. Dan garis kontinum hasil rasa formulasi P2 menunjukan nilai 3,50 yang menunjukkan kategori suka.

\section{Panelis Ahli}

Jumlah panelis ahli yang tidak suka terhadap rasa formulasi P2 berjumlah 1 orang $(50 \%)$ dan suka terhadap rasa formulasi P2 berjumlah 1 orang $(50 \%)$. Dengan nilai rata-rata mean menunjukkan angka 2,50, nilai tengah median menunjukkan angka 2,50, nilai yang sering muncul modus menunjukkan angka 2 dan hasil nilai standar deviasi menunjukkan angka 0,707. Dan garis kontinum hasil rasa formulasi P2 menunjukan nilai 2,50 yang menunjukkan kategori tidak suka

Jumlah panelis ahli yang suka terhadap rasa formulasi P3 berjumlah 1 orang $(50 \%)$ dan sangat suka terhadap rasa formulasi P3 berjumlah 1 orang $(50 \%)$. Dengan nilai rata-rata mean menunjukkan angka 3,50, nilai tengah median menunjukkan angka 3,50, nilai yang sering muncul modus menunjukkan angka 3 dan hasil nilai standar deviasi menunjukkan angka 0,707. Dan garis kontinum hasil rasa formulasi P2 menunjukan nilai 3,50 yang menunjukkan kategori suka.

\section{Panelis Konsumen}

Jumlah panelis Konsumen yang tidak suka terhadap rasa formulasi P2 berjumlah 37 orang (74\%) suka terhadap rasa formulasi $\mathrm{P} 2$ berjumlah 12 orang (24\%) dan sangat suka terhadap rasa formulasi P2 berjumlah 1 orang (2\%). Dengan nilai rata-rata mean menunjukkan angka 2,28, nilai tengah median menunjukkan angka 2,00, nilai yang sering muncul modus menunjukkan angka 2 dan hasil nilai standar deviasi menunjukkan angka 0,497. Dan garis kontinum hasil rasa formulasi P2 menunjukan nilai 2,28 yang menunjukkan kategori tidak suka.

Jumlah panelis Konsumen yang tidak suka terhadap rasa formulasi P3 berjumlah 2 orang (4\%), suka terhadap rasa formulasi P3 berjumlah 25 orang $(50 \%)$ dan sangat suka terhadap rasa formulasi P3 berjumlah 23 orang (46\%). Dengan nilai rata-rata mean menunjukkan angka 3,42, nilai tengah median menunjukkan angka 3,00, nilai yang sering muncul modus menunjukkan angka 3 dan hasil nilai standar deviasi menunjukkan angka 0,575. Dan garis kontinum hasil rasa formulasi P2 menunjukan nilai 3,42 yang menunjukkan kategori suka.

\section{Hasil Data Berdasarkan Aspek Warna}

\section{Panelis Ahli}

Jumlah panelis ahli yang suka terhadap warna formulasi P2 berjumlah 2 orang (100\%). Dengan nilai rata-rata mean menunjukkan angka 3,00, nilai tengah median menunjukkan angka 3,00 , nilai yang sering muncul modus menunjukkan angka 3 dan hasil nilai standar deviasi menunjukkan angka 0,000. Dan garis kontinum hasil warna formulasi P2 menunjukan nilai 3,00 yang menunjukkan kategori suka. 
Panelis ahli yang sangat suka terhadap warna formulasi P3 berjumlah 2 orang (100\%). Dengan nilai rata-rata mean menunjukkan angka 4,00, nilai tengah median menunjukkan angka 4,00, nilai yang sering muncul modus menunjukkan angka 4 dan hasil nilai standar deviasi menunjukkan angka 0,000. Dan garis kontinum hasil warna formulasi P3 menunjukan nilai 4,00 yang menunjukkan kategori sangat suka.

\section{Panelis Konsumen}

Jumlah panelis Konsumen yang tidak suka terhadap warna formulasi P2 berjumlah 26 orang $(52 \%)$, suka terhadap warna formulasi P2 berjumlah 20 orang $(40 \%)$, dan sangat suka terhadap warna formulasi P2 berjumlah 4 orang (8\%). Dengan nilai rata-rata mean menunjukkan angka 2,56, nilai tengah median menunjukkan angka 2,00, nilai yang sering muncul modus menunjukkan angka 2 dan hasil nilai standar deviasi menunjukkan angka 0,644. Dan garis kontinum hasil warna formulasi P2 menunjukan nilai 2,56 yang menunjukkan kategori tidak suka.

Jumlah panelis Konsumen yang tidak suka terhadap warna formulasi P3 berjumlah 4 orang $(8 \%)$, suka terhadap warna formulasi P3 berjumlah 24 orang (48\%), dan sangat suka terhadap warna formulasi P3 berjumlah 22 orang $(44 \%)$. Dengan nilai rata-rata mean menunjukkan angka 3,36, nilai tengah median menunjukkan angka 3,00, nilai yang sering muncul modus menunjukkan angka 3 dan hasil nilai standar deviasi menunjukkan angka 0,631. Dan garis kontinum hasil warna formulasi P3 menunjukan nilai 3,36 yang menunjukkan kategori suka.

\section{Hasil Data Berdasarkan Aspek Aroma}

\section{Panelis Ahli}

Jumlah panelis ahli yang suka terhadap aroma formulasi P2 berjumlah 2 orang (100\%). Dengan nilai rata-rata mean menunjukkan angka 3,00 , nilai tengah median menunjukkan angka 3,00, nilai yang sering muncul modus menunjukkan angka 3 dan hasil nilai standar deviasi menunjukkan angka 0,000. Dan garis kontinum hasil warna formulasi P2 menunjukan nilai 3,00 yang menunjukkan kategori suka.

Jumlah panelis ahli yang suka terhadap aroma formulasi P3 berjumlah 2 orang (100\%). Dengan nilai rata-rata mean menunjukkan angka 3,00, nilai tengah median menunjukkan angka 3,00 , nilai yang sering muncul modus menunjukkan angka 3 dan hasil nilai standar deviasi menunjukkan angka 0,000. Dan garis kontinum hasil warna formulasi P3 menunjukan nilai 3,00 yang menunjukkan kategori suka.

\section{Panelis Konsumen}

Jumlah panelis Konsumen syang tidak suka terhadap aroma formulasi P2 berjumlah 32 orang (64\%), suka terhadap aroma formulasi P2 berjumlah 17 orang (34\%) dan samgat suka terhadap aroma formulasi P2 berjumlah 1 orang (2\%). Dengan nilai rata-rata mean menunjukkan angka 2,38, nilai tengah median menunjukkan angka 2,00, nilai yang sering muncul modus menunjukkan angka 2 dan hasil nilai standar deviasi menunjukkan angka 0,530. Dan garis kontinum hasil warna formulasi P2 menunjukan nilai 2,38 yang menunjukkan kategori tidak suka. Dari tabel diatas dapat disimpulkan bahwa jumlah panelis Konsumen yang tidak suka terhadap aroma formulasi P3 berjumlah 7 orang (14\%), suka terhadap aroma formulasi P3 berjumlah 33 orang (66\%) dan samgat suka terhadap aroma formulasi P3 berjumlah 10 orang (20\%). Dengan nilai rata-rata mean menunjukkan angka 3,06, nilai tengah median menunjukkan angka 3,00, nilai yang sering muncul modus menunjukkan angka 3 dan hasil nilai standar deviasi menunjukkan angka 0,586. Dan garis kontinum hasil warna formulasi P3 menunjukan nilai 3,06 yang menunjukkan kategori suka.

\section{Hasil Data Berdasarkan Aspek Tekstur Panelis Ahli}

Jumlah panelis ahli yang suka terhadap tekstur formulasi P2 berjumlah 2 orang (100\%). Dengan nilai rata-rata mean menunjukkan angka 3,00, nilai tengah median menunjukkan angka 3,00, nilai yang sering muncul modus menunjukkan angka 3 dan hasil nilai standar deviasi menunjukkan angka 0,000.Dan garis kontinum hasil warna formulasi P2 menunjukan nilai 3,00 yang menunjukkan kategori suka.

Jumlah panelis ahli yang suka terhadap tekstur formulasi P3 berjumlah 1 orang (50\%), dan sangat suka terhadap tekstur formulasi P3 berjumlah 1 orang $(50 \%)$. Dengan nilai rata-rata mean menunjukkan angka 3,50, nilai tengah median menunjukkan angka 3,50 , nilai yang sering muncul modus menunjukkan angka 3 dan hasil nilai standar deviasi menunjukkan angka 0,707.

Dan garis kontinum hasil warna formulasi P3 menunjukan nilai 3,50 yang menunjukkan kategori suka.

\section{Panelis Konsumen}


Jumlah panelis Konsumen yang tidak suka terhadap tekstur formulasi P2 berjumlah 19 orang $(38 \%)$, suka terhadap tekstur formulasi P2 berjumlah 27 orang (54\%), dan sangat suka terhadap tekstur formulasi P2 berjumlah 4 orang (8\%). Dengan nilai rata-rata mean menunjukkan angka 2,70, nilai tengah median menunjukkan angka 3,00 , nilai yang sering muncul modus menunjukkan angka 3 dan hasil nilai standar deviasi menunjukkan angka 0,614. Dan garis kontinum hasil warna formulasi P2 menunjukan nilai 2,70 yang menunjukkan kategori tidak suka.

Jumlah panelis Konsumen yang suka terhadap tekstur formulasi P3 berjumlah 29 orang (58\%), dan sangat suka terhadap tekstur formulasi P3 berjumlah 21 orang (42\%). Dengan nilai rata-rata mean menunjukkan angka 3,42 , nilai tengah median menunjukkan angka 3,00 , nilai yang sering muncul modus menunjukkan angka 3 dan hasil nilai standar deviasi menunjukkan angka 0,499. Dan garis kontinum hasil warna formulasi P3 menunjukan nilai 3,42 yang menunjukkan kategori suka

\subsection{Pembahasan}

Berikut ini adalah hasil kesimpulan keseluruhan perhitungan kuesioner panelis ahli dan panelis tidak ahli dari produk "Inovasi Tepung Kacang Merah Dalam Pembuatan Kulit Mooncake".

\section{Panelis Ahli}

Tabel 82. Kesimpulan Hasil Kuesioner Panelis Ahli

\begin{tabular}{|c|c|c|c|c|c|c|}
\hline Formulas & Dimensi & Total Skor & Mean & Median & Modus & Standar Deviasi \\
\hline \multirow[t]{4}{*}{$\mathrm{P} 2$} & Rasa & 2.50 & 2.50 & 2.50 & 2 & 0.707 \\
\hline & Warna & 3.00 & 3.00 & 3.00 & 3 & 0.000 \\
\hline & Aroma & 3.00 & 3.00 & 3.00 & 3 & 0.000 \\
\hline & Tekstur & 3.00 & 3.00 & 3.00 & 3 & 0.000 \\
\hline \multirow[t]{4}{*}{ P3 } & Rasa & 3.50 & 3.50 & 3.50 & 3 & 0.707 \\
\hline & Warna & 4.00 & 4.00 & 4.00 & 4 & 0.000 \\
\hline & Aroma & 3.00 & 3.00 & 3.00 & 3 & 0.000 \\
\hline & Tekstur & 3.50 & 3.50 & 3.50 & 3 & 0.707 \\
\hline \multicolumn{2}{|c|}{ Total } & 25.50 & 25.50 & 25.50 & 24 & 2.121 \\
\hline \multicolumn{2}{|c|}{ Rata-Rata } & 3.19 & 3.19 & 3.19 & 3 & 0.265 \\
\hline
\end{tabular}

Sumber: Hasil Olah Data, 2021

Pada pembuatan produk "Inovasi Tepung Kacang Merah Dalam Pembuatan Kulit Mooncake” maka dapat disimpulkan hasil olah data panelis ahli pada tabel diatas, bahwa hasil nilai dari keseluruhan data kuesioner panelis ahli terhadap aspek rasa, warna, aroma dan tekstur dalam 2 formulasi percobaan. Hasil dari aspek rasa dalam 2 formulasi percobaan menunjukkan total angka 3,00 yang menunjukkan kategori suka, Hasil dari aspek warna dalam 2 formulasi percobaan menunjukkan total angka 3,50 yang menunjukkan kategori suka, Hasil dari aspek aroma dalam 2 formulasi percobaan menunjukkan total angka 3,00 yang menunjukkan kategori suka, Hasil dari aspek tekstur dalam 2 formulasipercobaan menunjukkan total angka 3,25 yang menunjukkan kategori suka.

Berdasarkan hasi penelitian kuesioner produk "Substitusi Tepung Kacang Merah Dalam Pembuatan Kulit Mooncake" nilai yang paling terendah untuk pertanyaan pada kuesioner adalah pada aspek rasa P2 dengan nilai angka menunjukkan 2,50, dan nilai tertinggi untuk pertanyaan pada kuesioner adalah pada aspek warna P3 dengan nilai menunjukkan angka 4,00. Maka hasil penelitian dapat disimpulkan bahwa para panelis ahli tertarik pada formulasi percobaan pembuatan kulit mooncake dengan menggunakan tepung kacang merah. Dari 2 formulasi percobaan P2 dan P3 dalam pembuatan kulit mooncake dengan menggunakan tepung kacang merah, dari hasil data kuesioner yang sudah ada para panelis ahli menyukai produk formulasi P3 dengan nilai total 3,5 dilihat dari hasil rasa, warna, aroma, dan tekstur pada data tabel diatas.

\section{Panelis Konsumen}

Tabel 9. Kesimpulan Hasil Kuesioner Panelis Konsumen

\begin{tabular}{|c|c|c|c|c|c|c|}
\hline Formulasi & Dimensi & Total Skor & Mean & Median & Modus & Standar Deviasi \\
\hline \multirow[t]{4}{*}{ P2 } & Rasa & 2.28 & 2.28 & 2.00 & 2 & 0.497 \\
\hline & Warna & 2.56 & 2.56 & 2.00 & 2 & 0.644 \\
\hline & Aroma & 2.38 & 2.38 & 2.00 & 2 & 0.530 \\
\hline & Tekstur & 2.70 & 2.70 & 3.00 & 3 & 0.614 \\
\hline \multirow[t]{4}{*}{ P3 } & Rasa & 3.42 & 3.42 & 3.00 & 3 & 0.575 \\
\hline & Warna & 3.36 & 3.36 & 3.00 & 3 & 0.631 \\
\hline & Aroma & 3.06 & 3.06 & 3.00 & 3 & 0.586 \\
\hline & Tekstur & 3.42 & 3.42 & 3.00 & 3 & 0.707 \\
\hline \multicolumn{2}{|c|}{ Total } & 23.18 & 23.18 & 21.00 & 21 & 4.784 \\
\hline \multicolumn{2}{|c|}{ Rata-Rata } & 2.90 & 2.90 & 2.63 & 2.625 & 0.499 \\
\hline
\end{tabular}

Pada pembuatan produk "Substitusi Tepung Kacang Merah Dalam Pembuatan Kulit Mooncake" maka dapat disimpulkan hasil olah data panelis Konsumen pada tabel diatas, bahwa hasil nilai dari keseluruhan data kuesioner panelis Konsumen terhadap aspek rasa, warna, aroma dan tekstur dalam 2 formulasi percobaan. Hasil dari aspek rasa dalam 2 formulasi percobaan menunjukkan total angka 2,85 yang menunjukkan kategori suka, Hasil dari aspek warna dalam 2 formulasi percobaan menunjukkan total angka 
2,96 yang menunjukkan kategori suka, Hasil dari aspek aroma dalam 2 formulasi percobaan menunjukkan total angka $\mathbf{2 , 7 2}$ yang menunjukkan kategori suka, Hasil dari aspek tekstur dalam 2 formulasi percobaan menunjukkan total angka 3,06 yang menunjukkan kategori suka.

Berdasarkan hasi penelitian kuesioner produk "Inovasi Tepung Kacang Merah Dalam Pembuatan Kulit Mooncake" nilai yang paling terendah untuk pertanyaan pada kuesioner adalah pada aspek rasa P2 dengan nilai angka menunjukkan 2,28, dan nilai tertinggi untuk pertanyaan pada kuesioner adalah pada aspek rasa dan tekstur P3 dengan nilai menunjukkan angka 3,42 .

Maka hasil penelitian dapat disimpulkan bahwa para panelis Konsumen tertarik pada formulasi percobaan pembuatan kulit mooncake dengan menggunakan tepung kacang merah. Dari 2 formulasi percobaan $\mathrm{P} 2$ dan $\mathrm{P} 3$ dalam pembuatan kulit mooncake dengan menggunakan tepung kacang merah, dari hasil data kuesioner yang sudah ada para panelis Konsumen menyukai produk formulasi P3 dengan nilai total 3,32 dilihat dari hasil rasa, warna, aroma, dan tekstur pada data tabel diatas

\section{SIMPULAN}

Dari 2 formulasi yang didapatkan dan dilihat dari nilai mean, median, modus, dan standar deviasi hasil dari kuesioner uji organoleptik terhadap para panelis ahli dan panelis konsumen maka dapat ditarik kesimpulan bahwa formulasi yang lebih di sukai baik dari segi rasa, aroma, warna dan tekstur adalah formulasi P3 dengan menggunakan 100\% tepung kacang merah dengan nilai rata-rata panelis ahli 3,5 dan panelis konsumen 3,32. Pembuatan kulit mooncake dengan menggunakan tepung kacang merah sebagai pengganti tepung terigu yang merupakan bahan utama dalam pembuatan kulit mooncake dapat disukai dan diterima oleh masyarakat. Karena dengan menggunakan tepung kacang merah, Selain meningkatkan kualitas dan nilai ekonomi tepung kacang merah, produk tersebut bisa menjadi salah satu makanan sehat dengan didukung bahan-bahan yang digunakan dalam pembuatan produk tersebut.

\section{DAFTAR PUSTAKA}

Firdhania, Melissa. 2020. "Pemanfaatan Tepung Kacang Merah Sebagai Bahan Dasar Pembuatan Kue Pukis.’Karya Tugas Akhir
Management Perhotelan, Sekolah Tinggi Pariwisata .

Praptiningrum, Wulan. 2015. "Eksperimen Pembuatan Butter Cookies Tepung Kacang Merah Substitusi Tepung Terigu”. Skripsi Jurusan Pendidikan Kesejahteraan Keluarga Fakultas Teknik, Universitas Negeri Semarang.

Prasetyo, Andri S., Dwi Ishartani, and Dian Rachmawanti Affandi. "Pemanfaatan Tepung Jagung (Zea Mays) Sebagai Pengganti Terigu Dalam Pembuatan Biskuit Tinggi Energi Protein Dengan Penambahan Tepung Kacang Merah (Phaseolus Vulgaris L)." Jurnal Teknosains Pangan 3.1 (2014).

Hanastiti, W.R. 2013. Pengaruh Subtitusi Tepung Singkong Terfermentasi dan Tepung Kcanag merah Terhadap Kadar protein, kadar serat, dan daya terima cake. (Naskah Publikasi) Program Studi S1 Gizi, Fakultas Muhammadiyah Surakarta.

Intan, Laila. 2018. "Inovasi Tepung Kacang Merah Dalam Pembuatan Red Bean Cheese Tart (RENCHEETA)”. Program Studi Teknik Boga Jurusan Pendidikan Teknik Boga Dan Busana Fakultas Teknik, Universitas Negeri Yogyakarta.

Setiawan, S. 2016. Pengertian Gizi Beserta Zat Gizi Menurut Para Ahli.

Tilohe, R. 2020 “ Analisis Peningkatan Nilai Gizi Produk Wapili (Waffle) yang Diformulasikan dengan Tepung Kacang Merah (Phaseolus vulgaris L.) Analysis of Increased Nutritional Value of Wapili Products (Waffles) Formulated with Red Bean Flour (Phaseolus vulgaris L.)". Skripsi Jurusan Ilmu dan Teknologi Pangan, Fakultas Pertanian Universitas Negeri Gorontalo.

Wahyuni, Aprilia. 2016. "Pemanfaatan Kacang Merah Dan Tepung Kacang Merah Dalam Pembuatan Red Bean Wellington Steak (Red Bewell Steak) Dan Bean Chocolate Cake (Bean Cho Cake)". Proyek Akhir Fakultas Teknik, Universitas Negeri Yogyakarta. 